\title{
Evaluation of the Implemented and Adopted Curriculum in Health Education in the Czech Republic with an Emphasis on the Drinking Regimen
}

Michaela Hřivnová ${ }^{1}$

$\approx$ According to the Framework Education Programme for Elementary Education in the Czech Republic, part of Health Education is nutrition and food intake, including the drinking regimen. This paper's objective is to analyse that using the results of two extensive curricular studies performed at the Faculty of Education, Palacký University Olomouc. Both studies used data from representative samples of pupils in grade nine from elementary schools in the Czech Republic. The research instruments were designed according to applicable documents of the statelevel implemented curriculum and showed good reliability. The results of the subjective evaluation of the implemented curriculum in health education suggest that in the area 'healthy lifestyle and health care', the subtopic 'nutrition and health - healthy diet principles, drinking regimen, eating disorders' was most dominant. The testing of the level of the adopted curriculum regarding fluid intake revealed a problematic level of pupils' knowledge (the average percentage of task achievement was around $46 \%$ ). Conclusions and recommendations for practice: nutrition and food intake (including the drinking regimen) is a very important topic in health education in elementary education in the Czech Republic, which is consistent with other research studies. However, the cognitive dimension of the pupils' curriculum is inadequate. Qualitatively and quantitatively, the recommended drinking regimen may support natural health determinants, while an inappropriate or insufficient regimen may result in medical complications. The issue of adequate nutrition and diet and drinking regime must be taught by professionally and didactically competent teachers. Students should not only be taught cognitively, but their affective and behavioural abilities should also be formed.

Keywords: curriculum, drinking regimen, evaluation, health education, nutrition

1 Faculty of Education, Palacký University Olomouc, Czech Republic; michaela.hrivnova@upol.cz. 


\section{Vrednotenje izvedenega in sprejetega učnega načrta za zdravstveno vzgojo na Češkem s poudarkom na režimu pitja}

Michaela Hřivnová

$\propto$ Skladno z Okvirnim izobraževalnim programom za osnovnošolsko izobraževanje na Češkem sta del zdravstvene vzgoje tudi prehrana in uživanje hrane, vključno $\mathrm{z}$ režimom pitja. Cilj prispevka je analizirati področje s pomočjo rezultatov dveh obsežnih kurikularnih študij, izvedenih na Pedagoški fakulteti Univerze Palacký v Olomoucu. V obeh raziskavah so bili uporabljeni podatki reprezentativnih vzorcev učencev devetega razreda osnovnih šol na Češkem. Raziskovalna instrumenta sta bila oblikovana skladno z veljavnimi dokumenti učnega načrta, ki se izvaja na državni ravni, in sta pokazala dobro zanesljivost. Rezultati subjektivnega vrednotenja izvedenega učnega načrta za zdravstveno vzgojo kažejo, da je na področju »zdravega življenjskega sloga in skrbi za zdravje« najbolj prevladovala podtema "prehrana in zdravje - načela zdrave prehrane, režim pitja in motnje hranjenja«. Preverjanje ravni usvojenega učnega načrta glede vnosa tekočin je pokazalo problematično raven znanja učencev (povprečni odstotek uspešnosti nalog je bil okoli $46 \%)$. Zaključki in priporočila za prakso: prehrana in uživanje hrane (vključno z režimom pitja) sta zelo pomembni temi pri zdravstveni vzgoji v osnovnem izobraževanju na Češkem, kar je skladno z drugimi raziskavami, vendar je kognitivna komponenta učnega načrta za učence neustrezna. Kvalitativno in kvantitativno lahko priporočeni režim pitja podpira temeljne dejavnike zdravja, medtem ko lahko neustrezen ali nezadosten režim povzroči zdravstvene zaplete. Vprašanje ustreznega prehranjevanja in prehrane ter režima pitja morajo poučevati strokovno in didaktično usposobljeni učitelji. Pri tem je pomembno, da učitelj poleg kognitivnega področja razvija tudi čustvene in vedenjske spretnosti učencev. Učence ne smemo poučevati le kognitivno, ampak moramo oblikovati tudi njihove afektivne in vedenjske sposobnosti.

Ključne besede: učni načrt, režim pitja, evalvacija, zdravstvena vzgoja, prehrana 


\section{Introduction and theoretical background}

In the context of the state-level intended curriculum in the Czech Republic (CR), health education is represented at all levels of the education system (ISCED o-ISCED 3). Lower secondary education (ISCED 2) offers space for health education as a separate educational field under the educational area 'Man and Health'. This area also includes 'Physical Education' (Framework Education Programme for Elementary Education - FEP EE, 2013, 2021).

Health education as a separate educational field and subject is included in the state-level curriculum in 10 (38\%) of 26 European countries, 16 (62\%) of which integrate health education in other educational fields (subjects), mostly are physical education, health and safety, personality and social education, home economics, nutrition, citizenship education, biology, and similar. (SHE Factsheet 1. State of the art: health-promoting schools in Europe, 2013). For example, in Slovenia, selected health education themes are included in the subject home economics (Kostanjevec et al., 2018). In the context of the state-level intended curriculum and the educational reality of lower secondary education in the CR, health education as a separate subject is delivered by over $90 \%$ of schools. $80 \%$ of schools call it 'health education', $11 \%$ refer to it as 'family education' or a different title, and only about $8 \%$ of elementary schools have integrated the content of health education into different subjects (mostly natural history, citizenship education or physical education), as suggested by Hřivnová (2014a).

The primary objective of health education is to shape and develop health literacy (Nutbeam, 2000), yet the term 'health literacy' is not explicitly mentioned in the Czech curriculum (Hřivnová, 2018d). Health education also aims to strengthen an active approach to health, promote an adequate lifestyle with an emphasis on the prevention of chronic non-communicable epidemics and selected communicable diseases, as well as the prevention of risk behaviour in various areas, including particularly addictive behaviour and risky sexual behaviour. In the latest versions of the FEP EE (since 2013), health education also includes civil protection in emergency situations and traffic education (Kovař́ḱková \& Marádová, 2020; Slaná Reissmannová, 2021). Given the mission of health education in the context of formal education, this is clearly a multidisciplinary field (Fialová et al., 2014; Hřivnová, 2014a, 2016, 2017, 2018a; Liba, 2016; Marádová, 2011; Mužíková, 2010). Regarding the formulated expected outcomes of the intended curriculum in health education and the broad range of the learning content of the subject (see below), it is clear that the concept of the educational field exceeds the boundaries of a single discipline and is based 
on (integrates the knowledge of) multiple scientific disciplines including medicine and its subdisciplines (i.e., paediatrics, sexology, preventive medicine, addictology, hygiene and epidemiology, psychology, sociology, demography, anthropology, kinanthropology, civil protection; traffic, etc.) (Fialová et al., 2014; Hřivnová, 2014a, 2016, 2017, 2018a; Marádová, 2011; Svoboda, 2015).

The content specifics are also expressed in the topicality of applicable information and knowledge as it evolves dynamically over time along with the current scientific knowledge of relevant disciplines. The content specifics are also based on the need to integrate the learning content in a comprehensive (holistic) approach that addresses the different themes from a bio-psycho-social perspective. This precondition is crucial as the thematic areas must not be limited to mere 'biologisation' (Hřivnová, 2018d; Leahy \& Simovska, 2017). An important aspect is to target the content (also in combination with applicable didactic aspects) so that the educational content allows the formation of educational outcomes and long-term health education effects not only in the cognitive dimension but also in the affective and conative or psychomotor dimensions (at the level of practical skills and behaviour). Considering this, an important aspect is the high-quality didactic transformation of the learning content and the so-called didactic specifics (for details, see Hřivnová, 2018d), which should be based on the principle of the experiential use of activating teaching methods and project-based forms of education.

For this reason, health education teachers should be provided with a sufficient portfolio of appropriate methodological and didactic resources (for details, see the following). The most frequent objection, as reported by citizenship education and health education teachers, is the absence of methodological guidance for teaching the different themes. This was reported by the Czech School Inspectorate in the final report Analysis of selected educational outcomes in grade 5 and 9 of elementary schools in the 2016/2017 school year (2017, p. 130). At the same time, health education teachers emphasise that some outcomes are difficult to comprehend. In order to promote the effectiveness of health education, this subject must be taught by qualified teachers, and sufficient time must be ensured for the educational process (Hřivnová, 2018b, 2018d).

This is the only way for health education to fulfil its social role, especially in the development of health literacy and influencing the future health of the citizens of the Czech Republic as defined by the objectives of Health 21 (1999), Health 2020 (2013), Health 2030 (2020).

The inclusion of this educational field in the system of elementary education is recommended by research studies on children's and adolescents' lifestyle, morbidity and mortality prevalence of the citizens of the Czech Republic, 
as well as studies examining the level of health literacy of the Czech population (Kučera et al., 2016; Madarasová-Gecková et al., 2016; Report on the health of the population of the Czech Republic, 2014).

The curricular document FEP EE has been mandatory in the Czech Republic since 2007; it has undergone several revisions. The major revision that affected health education took place in 2013. In the Czech Republic, the field of health education currently defines 16 expected outcomes (educational objectives) that should be achieved by the end of compulsory education (grade nine of elementary school) (Hřivnová, 2014a; FEP EE, 2013, 2021). Many of them are linked to the pupils' everyday life (present and future) in the bio-psychosocial aspects of their health. The learning content is divided into the following six thematic areas: (1) interpersonal relations and forms of coexistence; (2) life changes and what they involve; (3) healthy lifestyle and self-care for health; (4) health risks and their avoidance; (5) value and promotion of health; and 6) personality and social development. Each of these themes includes sub-themes that were significantly updated in 2013. In the latest revision of the FEP EE, valid since 2021, amendments relate to the promotion of digital literacy. The curricular documents also include the Standards for elementary education - Health education (2015) and Methodological guidelines and tasks for the Standards for elementary education - Health education (2016), which specify and extend the FEP EE (see below).

A significant health education theme is adequate nutrition and food intake, including the drinking regimen. According to Hřivnová (2014b), nutrition is integral to human life. Food and fluid intake saturates the basic (physiological) needs of the body and provides the basic nutrients (macronutrients) as well as secondary nutrients (micronutrients) and water. However, human nutrition and the development of nutrition habits also have a strong psychosocial and culturally conditioned overlap. During ontogenetic development, specific nutritional requirements are defined for individual population groups, both in terms of quantity and quality. At the same time, human nutrition is one of the most important lifestyle determinants and, in terms of health, can have a strong positive (promoting and protective) effect, provided that adequate dietary habits are in place (in terms of quantity, quality or frequency of food intake as well in terms of hygienic handling, culinary preparation, etc.) If adequate dietary habits are not observed, malnutrition may result in various diseases (in particular, chronic non-communicable epidemics, previously referred to as lifestyle diseases: obesity, atherosclerosis-based cardiovascular diseases, some types of cancer including colorectal cancer, type II diabetes mellitus, etc.) Nonobservance of hygienic aspects in food handling may result in the so-called 
alimentary diseases (e.g., salmonellosis). A proper dietary regimen can also be a preventive or therapeutic tool for many diseases (allergy, coeliac disease, diabetes, digestive tract disease, etc.).

Specific eating habits in the current Czech population of adolescents have been reported by the results of the international Health Behaviour in School-Aged Children: WHO Collaborative Cross-National Study (HBSC), which has been carried out every four years since 1982; the Czech Republic joined the study in 1994 (Kalman et al., 2011). In the area of health, Czech girls showed worse self-evaluation compared with the HBSC average, and the percentage of girls with a negative evaluation of their health has been reported to increase with age (category of 11 years: $15 \%$ of Czech girls - HBSC average $10 \%$; category of 13 years: $20 \%$ - HBSC average $16 \%$; category of 15 years: $22 \%$ - HBSC average $21 \%)$. This trend is also evident in all age groups of Czech boys. Overweight and obesity was observed in $15 \%$ of 11 -year-old girls and $12 \%$ of 13 - and 15 -year-old girls. In boys, the proportion was $29 \%$ in the age category of $11,28 \%$ in the age category of 13 and $23 \%$ in the age category of 15 years. In assessing their own body, a positive response to 'a bit too fat or much too fat' was indicated by $27 \%$ of 11 -year-old girls and $38 \%$ of 13 - and 15 -year-old girls. Among boys, the positive response was indicated by $21 \%$ and $29 \%$ of respondents; $37 \%$ of 15 -year-old girls and $19 \%$ of boys were on a diet. The results concerning nutrition habits suggest that with increasing age, the proportion of pupils who consume their breakfast regularly decreases (in the age category of 11 years, only $66 \%$ of girls and boys have their breakfast regularly; in the category of 15 years, the proportion is only $53 \%$ of boys and $44 \%$ of girls). A similar trend was also observed in the case of daily consumption of fruit; in the category of 11-year-olds, only $49 \%$ of girls and $40 \%$ of boys consume fruit daily, while among 15 -year-old adolescents, the proportion is only $34 \%$ of girls and $26 \%$ of boys (MadarasováGecková et al., 2016).

The dietary guidelines defined for the Czech Republic were updated in January 2021. They are intended for healthy persons to prevent chronic, noncommunicable (lifestyle) diseases, which are significantly affected by proper nutrition. The preamble to these guidelines is the following slogan: There is no unhealthy food - it is the amount that is unhealthy (Dostálová \& Tláskal, 2021, p. 25). The dietary guidelines are also specifically adapted for children. From these guidelines, we have selected a recommendation on the drinking regimen because the knowledge of qualitative and quantitative aspects of fluid intake is the subject of the present research study:

Never forget about fluid intake; especially at an early age, it is important to provide children with a sufficient amount of drink. Children should 
also drink between meals at least six times a day. During breakfast and in the morning, regular drinks prevent hidden dehydration and promote attention and school achievement. Suitable drinks include drinking water, slightly mineralised and preferably non-carbonated mineral water, mild tea, fruit tea and juice, preferably unsweetened or diluted. Reduce the consumption of sweetened and flavoured drinks. Children should not drink coffee, energy drinks and, of course, alcohol (Tláskal, 2021, p. 37).

It should also be added that the drinking regimen is an integral part of developing adequate nutrition habits. In terms of both qualitative (type of drink) and quantitative (amount of drink) aspects, the recommended principles concerning the drinking regimen may support the natural health determinants, while an inappropriate or insufficient drinking regimen may result in health problems (Doležel, 2007; Fraňková et al., 2013; Hřivnová, 2014b; Koží̌sek, 2005; Van Draanen et al., 2018). Tláskal (2021, p. 40) also emphasises that regular reminders about the drinking regimen is not useless as research has shown that if pupils (about 10 years old) fail to drink at least $250 \mathrm{ml}$ of drink for breakfast and at least $400 \mathrm{ml}$ of drink in the morning, the osmotic concentration of their urine corresponds to the state of body dehydration. This fact may also be associated with worse academic achievement.

Returning to nutrition in education in the context of Health education as defined by the Czech curriculum for lower secondary education, this theme is mostly included in expected outcome 7: HE-9-1-07 The pupil shall put the composition of one's diet and eating habits in connection with the development of lifestyle diseases, and apply healthy eating habits within his/her possibilities (FEP EE, 2013, p. 76; FEP EE, 2021, p. 91).

In an international comparison, the Slovenian curriculum includes the area of nutrition in the home economics domain, which is significantly associated with human health and sustainable development (Erjavšek et al., 2021; Kostanjevec et al., 2018).

\section{Objectives}

The main objective of the paper is to present the partial results, including their application possibilities of two extensive educational research studies carried out by the Faculty of Education, Palacký University Olomouc, with an emphasis on analysis and evaluation of the implemented and adopted curriculum in health education in the Czech Republic with a primary focus on nutrition and fluid intake. The sub-objectives can be defined as follows: 
1. On the basis of pupils' subjective evaluation, determine whether the first sub-theme Nutrition and health - healthy diet principles, drinking regimen, eating disorders under the third thematic unit healthy lifestyle and health care of the educational field health education defined pursuant to the Framework Education Programme for Elementary Education (2013) is meaningfully represented in schools or not and to what degree this sub-theme is popular among pupils.

2. Evaluate the level of the pupils' adopted curriculum in health education through detection of the level of their academic achievement relating to the expected outcome HE-9-1-07 and using an indicator of a criterionreferenced achievement test designed in compliance with the illustrative tasks as defined in Standards for elementary education - Health education (2015).

3. Introduce the applicability of the research results in the development of an accompanying curricular document Methodological guidelines and tasks for the Standards for elementary education - Health education, which is the sought-after methodological platform for health education and which is considered a crucial document by teachers. Emphasise the existence of other appropriate methodological and didactic resources for nutrition-based education.

\section{Method}

To achieve the objectives defined above, the following two curricular research studies were performed: Health education from the perspective of elementary school students and teachers and Research of the level of adopted curriculum by elementary school students in Health education.

The study Health education from the perspective of elementary school students and teachers allows subjective evaluation of the implemented curriculum in HE and evaluation of the dominant, absent and preferred topics in the educational reality in line with the learning content defined by FEP EE. The research study involved a representative sample of 755 pupils (397 girls (52.58\%); 358 boys $(47.42 \%)$ ) from grade nine from 23 elementary schools in five regions of the Czech Republic. The research tool was a questionnaire constructed by the authors and divided into two parts. The first block contained a set of items allowing the evaluation of pupils' perspective of the educational field and thus allowing the subjective evaluation of health education by pupils according to their own experience with the implementation of health education (for details, see Hřivnová, 2018c). The second block of the questionnaire, the assessment 
of which is the subject of this paper, was designed on the basis of categorical systems of the learning content of health education pursuant to FEP EE, version 2013 (FEP EE, 2013, pp. 76-78). It contained a total of six core thematic areas, including sub-thematic units. In each area, pupils reflected on which thematic sub-units (sub-themes) were given the greatest attention (dominant themes), which themes were neglected (absent themes) and which sub-themes were the most popular (preferred themes). This paper includes an evaluation of the third learning thematic unit: 3. Healthy lifestyle and health care. This thematic unit includes five sub-areas, the first of which relates to 1. Nutrition and health fundamentals of a healthy diet, fluid intake, eating disorders (FEP EE, 2013, p. 77; 2021, p. 92).

The second study, Research of the level of adopted curriculum by elementary school students in health education, considers the evaluation of the adopted curriculum at the end of compulsory education. The study involved a representative sample of 910 pupils (459 girls (50.44\%) and 451 boys (49.56\%)) from grade nine from 29 elementary schools in five regions of CR. The research tool used to achieve the research objectives was an evaluation instrument designed by the authors. This achievement test for health education may be defined as a criterion-referenced achievement test or an absolute performance test (pursuant to the requirements, as specified by Chráska, 2007). The success criterion represents the predetermined level of the learning content. The test items reflected the 16 defined expected outcomes of Health education pursuant to FEP EE 2013 (p. 76). Therefore, the achievement test contained 16 items, which were based on the illustrative tasks set out in the Standards for elementary education - Health education (most of them were identical). In the evaluation of the test in terms of its correct completion, the maximum point score was 16 ( 1 test item $=1$ point). Using the so-called weighted points is based on correct answers to the test items: more specifically, the number of correct operations included in the 16 test (illustrative) tasks. Overall, provided that all of the achievement test items are correct, a total of 108 weighted points is obtained. This analysis allows for a 'more sensitive' evaluation of the achieved level of the learners' educational outcomes, meaning evaluation of the adopted curriculum by learners with respect to the expected outcomes of health education (FEP EE, 2013, p. 76) based on the correct completion of the test items, also with respect to the educational standards.

This paper provides a detailed evaluation of Test Item 7 related to the expected Outcome 7, pursuant to FEP EE (2013, p. 76); the illustrative task associated with this outcome included in the Standards for elementary education - Health education. The maximum number of weighted points in this item was 14 . 
In both studies, pupils (and directors of the elementary schools involved) were guaranteed anonymity in the processing, evaluation, interpretation and presentation of the data obtained. Data processing was carried out in compliance with standard practices and procedures (Gavora, 2010; Hendl, 2006). The data were analysed using the MS Excel software and the STATISTICA 10 $\mathrm{CZ}$ programme, which used tables of frequency, as well as traditional statistical methods, such as the Student t-test, chi-square test, and similar (Chráska, 2007). The level of significance was set at $\mathrm{p}<.05$.

Prior to the evaluation, the reliability of the achievement test was determined with Cronbach's alpha and achieved .76. Cronbach's alpha calculation was performed using the STATISTICA $\mathrm{Cz}$ 10 package.

\section{Results and discussion}

\section{Evaluation of the implemented curriculum in Health education with an emphasis on nutrition}

As mentioned above, in the Czech curriculum for lower secondary education, nutrition is mostly included in the third thematic unit of health education, which is Healthy lifestyle and health care. Specifically, this thematic unit includes the following five sub-units: (1) nutrition and health - healthy diet principles, drinking regimen, eating disorders, (2) effects of external and internal environment on health, (3) physical and mental hygiene, daily regimen, physical activity regimen, (4) protection from infectious diseases, ways of transmission of infections and their prevention, and (5) protection from chronic non-communicable diseases, fundamentals of first aid.

Based on the subjective evaluation of the implemented curriculum (Research I) in health education by 755 pupils from grade nine of elementary schools, it was observed that within the thematic unit healthy lifestyle and health care the most dominant sub-unit as identified by $58 \%$ of pupils was nutrition and health - healthy diet principles, drinking regimen, eating disorders (Figure 1). 


\section{Figure 1}

Analysis of subjective evaluation of the dominant, absent and preferred themes in the thematic unit 'Healthy lifestyle and health care' in Health education by pupils from grade nine of elementary schools.

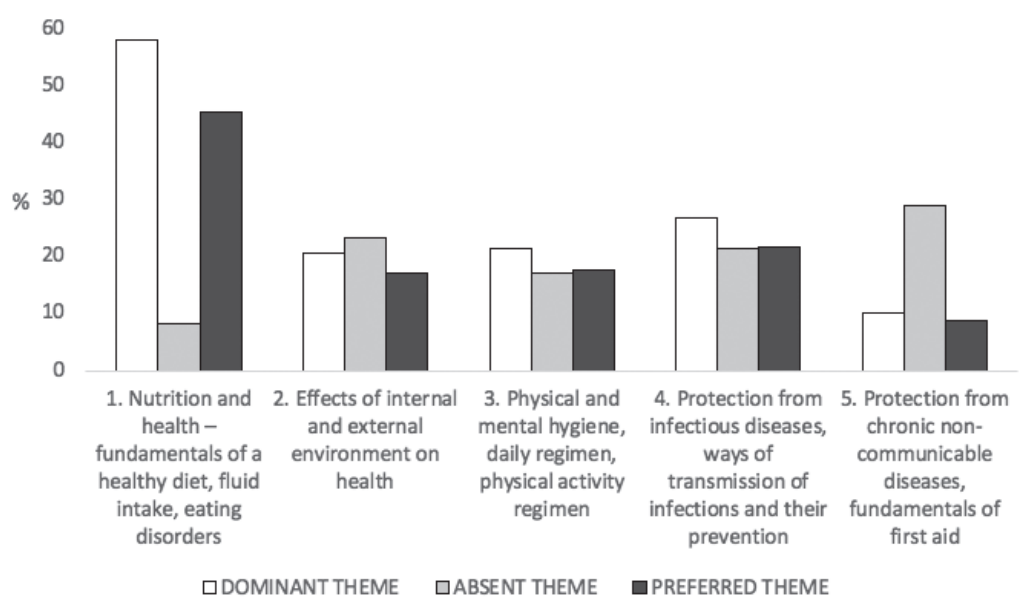

Nutrition was identified as the most dominant sub-theme across all six thematic units of health education (Hřivnová, 2018d), which is in long-term agreement with the results of research studies aimed at the implemented curriculum in Health education. According to teachers, the most dominant thematic health education unit is nutrition (Hřivnová, 2014a). A positive finding is pupils' relative interest in nutrition because it is a crucial lifestyle determinant (together with physical activity) that affects the prevention or potential manifestation of chronic non-communicable epidemics as confirmed by research studies and statistical analyses, for example, Müllerová (2003) or Rippe and Angelopoulos (2017). In the context of the learning content, the focus of this thematic unit (area) is in synergy with many expected outcomes of health education, including, for example, HE-9-1-07, HE-9-1-08, HE-9-1-10, etc. (cf. FEP EE, 2013, p. 76 or FEP EE, 2021, pp. 93-94). Purple et al. (2014, p. 139) claims that the thematic unit healthy lifestyle and health care is the second most frequently implemented theme in the school-level implemented curriculum (i.e., the School Education Programme (SEP)), which has been confirmed by an analysis of 160 SEPs conducted in 2008. The thematic unit healthy lifestyle and health care is closely linked with the development of pupils' health literacy, especially the dimensions of health promotion and disease prevention (according to the classification by Holčík et al., 2015). 
A detailed analysis of the preference of nutrition by pupils' gender suggests that both boys and girls show identical levels of interest in health education without a statistical difference (see Table 1). In the context of health education, nutrition was preferred by about $45 \%$ of 755 pupils.

\section{Table 1}

Analysis of subjective evaluation of the dominant, absent and preferred theme of nutrition in the thematic unit 'Life changes and what they involve' in Health education by pupils from grade nine of elementary schools

\begin{tabular}{|c|c|c|c|c|c|c|c|c|c|c|}
\hline \multirow{2}{*}{$\begin{array}{l}\text { HEALTHY } \\
\text { LIFESTYLE } \\
\text { AND SELF } \\
\text { CARE FOR } \\
\text { HEALTH }\end{array}$} & \multicolumn{3}{|c|}{ DOMINANT THEME } & \multicolumn{3}{|c|}{ ABSENT THEME } & \multicolumn{4}{|c|}{ PREFERRED THEME } \\
\hline & $\begin{array}{c}\text { Girls } \\
\%\end{array}$ & $\begin{array}{c}\text { Boys } \\
\%\end{array}$ & $\begin{array}{c}\text { Total } \\
\%\end{array}$ & $\begin{array}{c}\text { Girls } \\
\%\end{array}$ & $\begin{array}{c}\text { Boys } \\
\%\end{array}$ & $\begin{array}{c}\text { Total } \\
\%\end{array}$ & $\begin{array}{c}\text { Girls } \\
\%\end{array}$ & $\begin{array}{c}\text { Boys } \\
\%\end{array}$ & $\begin{array}{c}\text { Total } \\
\%\end{array}$ & $\mathrm{p}$ \\
\hline $\begin{array}{l}\text { Nutrition } \\
\text { and health - } \\
\text { fundamentals } \\
\text { of a healthy } \\
\text { diet, fluid } \\
\text { intake, eating } \\
\text { disorders }\end{array}$ & 58.94 & 56.70 & 57.88 & 7.56 & 8.94 & 8.21 & 47.61 & 42.74 & 45.30 & .18 \\
\hline
\end{tabular}

According to the subjective evaluation of the implemented curriculum in health education, pupils consider the subject to be popular and especially appreciate the fact that they can use the knowledge, attitudes and skills acquired in lower secondary education in their personal lives, now or in the future (Hřivnová, 2018c). The analyses identified the effect or confirmed the positive trend of selected factors of the educational reality, such as HE teacher qualification, more HE lessons, implementation of health promotion projects on the subjective evaluation of the implemented curriculum in the subject by pupils from grade nine of elementary schools. Those pupils taught by a qualified teacher had more HE classes than prescribed by the curricular document FEP EE (2013), were involved in projects aimed at health promotion and reported greater popularity of the subject, as well as the fact that they looked forward to HE classes. They confirmed the use of activating teaching methods in HE classes and that these methods motivate them to learn and gain new knowledge. Those pupils who had more lessons and participated in projects confirmed a frequent use of textbooks and worksheets in the subject. The most important finding is that those pupils who are taught by a qualified teacher and those with a higher number of lessons significantly agree that they can use the knowledge, skills and attitudes gained in their personal lives (Hřivnová, 2018b). 


\section{Evaluation of the adopted curriculum in health education with an emphasis on nutrition and fluid intake}

The evaluation of the adopted curriculum in health education (Research II) by 910 pupils from grade nine (i.e., the evaluation of the achieved level of educational outcomes) was performed by means of testing fully in compliance with the setting of the required level of the expected outcomes pursuant to FEP $\mathrm{EE}(2 \mathrm{O} 13,2 \mathrm{O} 21)$ using the test/illustrative tasks adopted from the curricular document Standards for elementary education - Health education (2015). To assess the output level of pupils' knowledge in the area of nutrition, it is necessary to present the results of the test task relating to the expected outcome 7 . The text of the expected outcome 7 and its elaboration into partial objectives in the form of indicators is shown in Figure 2.

\section{Figure 2}

HE Formulation of expected outcome 7 (HE-9-1-07) pursuant to FEP EE 2013 (2021) and the indicators defined in the Standards for elementary education Health education

\begin{tabular}{|c|c|}
\hline $\begin{array}{l}\text { Educational } \\
\text { field }\end{array}$ & Health education \\
\hline Grade & 9 \\
\hline \multicolumn{2}{|l|}{$\begin{array}{l}\text { Thematic } \\
\text { unit }\end{array}$} \\
\hline $\begin{array}{l}\text { Expected } \\
\text { outcome as } \\
\text { per FEP EE }\end{array}$ & $\begin{array}{l}\text { HE-9-1-07 } \\
\text { The pupil shall put the composition of one's diet and eating habits in connection } \\
\text { with the development of lifestyle diseases and apply healthy eating habits within } \\
\text { his/her possibilities }\end{array}$ \\
\hline Indicators & $\begin{array}{l}\text { 1. The pupil is able to explain the importance of the basic nutrients (proteins, fats, } \\
\text { carbohydrates), by-nutrients (vitamins and minerals) and water for the body } \\
\text { and to give examples of the sources of nutrients in food, } \\
\text { 2. The pupil is able to recognise the proper diet and drinking regimen that pro- } \\
\text { mote health and minimise harm as well as to apply the principles of good diet at } \\
\text { school, } \\
\text { 3. The pupil is able to select foodstuffs and food groups based on the current } \\
\text { nutritional recommendations (including restricted intake of simple sugars, inap- } \\
\text { propriate and hidden fats, and consumption of vegetables, fruit and cereals, etc. } \\
\text { several times a day), } \\
\text { 4. The pupil is able to determine which factors influence his/her nutrition (family, } \\
\text { culture, media, including advertising, hunger, taste, time, etc.) and to be aware } \\
\text { of the positive and negative impacts on eating habits, } \\
\text { 5. The pupil is able to explain the effect of nutrition as one of the lifestyle factors } \\
\text { on health and lifestyle (chronic non-communicable) diseases (type II diabetes, } \\
\text { obesity, tooth decay, cardiovascular diseases, cancer, etc.), } \\
\text { 6. The pupil is able to discuss eating disorders (anorexia nervosa and bulimia } \\
\text { nervosa), including their onset and symptoms. }\end{array}$ \\
\hline
\end{tabular}

Note. Adapted from Standards for elementary education - Health education, 2015, p. 9. 
The test task (Figure 3) assigned to pupils is an identical transcription of the illustrative task specified in the standards for this particular expected outcome and is related to Indicator 2. The objective of the illustrative task is to support pupils in the selection of adequate drinks into their drinking regimen. In the educational process, pupils need to be able to justify their choice and to give arguments why some drinks are better than others.

\section{Figure 3}

Assignment of test task 7 of the criterion-referenced achievement test in Health education relating to the evaluation of expected outcome HE-9-1-07

7. Use the symbols to identify the drinks that are suitable for daily consumption (you can drink them safely all day, the symbol is the pitcher), drinks that can be consumed daily but in a limited amount (the symbol is the larger glass, approx. $0.5 \mathrm{I}$ ), drinks that should be consumed occasionally (the symbol is the smaller glass, approx. $0.2 \mathrm{l}$ ) and drinks that should not be consumed at all (the symbol is the crossed drop).

Drinking tap water

Black tea

Cola drink

Fruit juice

Energy drink

Beer and other alcoholic beverages

Coffee with caffeine

Mineral water, medium mineralised

Bottled non-carbonated spring water

Sweetened lemonade

Slightly mineralised water

Carbonated drink

Green tea

Lemonade sweetened with artificial sweetener

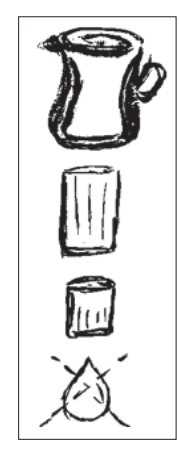

\section{Correct solution of the test task:}

- Pitcher: drinking tap water, bottled non-carbonated spring water, slightly mineralised water

- Large glass: black tea, fruit juice, mineral water medium mineralised, green tea

- Small glass: cola drink, sweetened lemonade, carbonated drink, lemonade sweetened with artificial sweetener

- Crossed drop: energy drink, beer and other alcoholic beverages, coffee with caffeine

Table 2 shows an analysis of the correct completion of the test task. The results suggest that only two out of $910(.22 \%)$ pupils from grade nine of 
elementary schools managed to complete the task correctly and matched all 14 drinks with the correct symbols indicating the recommended daily consumption. No statistically significant differences were observed between the results of girls and boys.

\section{Table 2}

Analysis of correct completion of the test task by gender

\begin{tabular}{|c|c|c|c|c|c|c|c|c|}
\hline $\begin{array}{l}\text { Correct completion of test task } 7 \text { / } \\
\text { EO HE-9-1-07 }\end{array}$ & 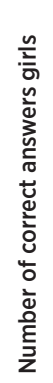 & 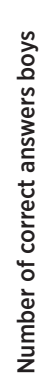 & 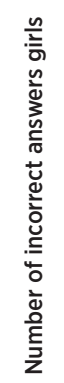 & 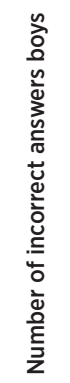 & 2 & 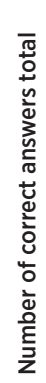 & 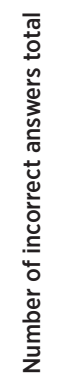 & 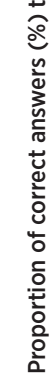 \\
\hline $\begin{array}{l}\text { Use the symbols to identify the } \\
\text { drinks that are suitable for daily } \\
\text { consumption, drinks that can be } \\
\text { consumed daily but in a limited } \\
\text { amount; drinks that should be con- } \\
\text { sumed occasionally and drinks that } \\
\text { should not be consumed at all. } \\
\text { HE-9-7-07 }\end{array}$ & 0 & 2 & 459 & 449 & .15 & 2 & 908 & .22 \\
\hline
\end{tabular}

The following evaluation stage awarded the so-called weighted points ( 1 point $=1$ correctly identified drink). The completion of the test task on the basis of the average number of weighted points is shown in Table 3. In terms of weighted points, significantly better results in the test task were achieved by girls than boys. On average, girls managed to categorise almost seven drinks while boys only did six. In this test item, girls' achievement was about $49 \%$, boys' achievement about $43 \%$. The combined achievement of the whole sample was $46 \%$. 


\section{Table 3}

Average weighted points and average achievement in the test task by gender

\begin{tabular}{|c|c|c|c|c|c|c|c|}
\hline $\begin{array}{l}\text { Average number } \\
\text { of correct sub-items } \\
\text { in test item } 7\end{array}$ & $\begin{array}{l}z \\
\bar{d} \\
\frac{o}{E} \\
\bar{z}\end{array}$ & 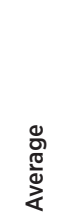 & 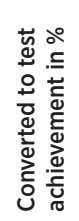 & e & 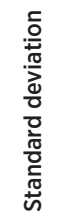 & 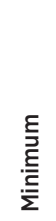 & 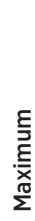 \\
\hline Girls & 459 & 6.80 & 48.57 & $.00^{* *}$ & 2.79 & .00 & 13 \\
\hline Boys & 451 & 5.99 & 42.79 & & 2.93 & .00 & 14 \\
\hline Total & 910 & 6.40 & 45.71 & - & 2.89 & .00 & 14 \\
\hline
\end{tabular}

The text below includes a detailed analysis of the results of the test task in terms of content, meaning the correct categorisation of the drinks according to the recommended amount of daily consumption for older school-aged children. It should be noted that the standards for elementary education require a minimum achievement of $80 \%$ in this task. However, the correct categorisation of the drinks following this guideline (10 cases out of 14) was achieved by less than half of pupils from grade nine of elementary schools (Table 4). The 80\% threshold was achieved only in one case (correct classification of 'drinking tap water'; $85.71 \%$ of pupils correctly indicated that drinking water can cover allday fluid intake - the pitcher symbol). The most frequent mistake was the item 'coffee with caffeine', which elementary school pupils should not consume at all (therefore, it should be matched with the symbol of the crossed drop). In the majority of cases, this drink was matched with the small glass symbol. 


\section{Table 4}

Analysis of the correct responses in the categorisation of the types of drinks according to their recommended amount, test task 7 , whole sample

\begin{tabular}{|c|c|c|c|c|c|c|c|c|c|c|c|}
\hline \multirow{2}{*}{\multicolumn{2}{|c|}{$\begin{array}{l}\text { Type of drink } \\
\text { (as ordered in the } \\
\text { test) }\end{array}$}} & \multicolumn{2}{|c|}{ Pitcher } & \multicolumn{2}{|c|}{ Large glass } & \multicolumn{2}{|c|}{ Small glass } & \multicolumn{2}{|c|}{ Crossed drop } & \multicolumn{2}{|c|}{ No answer } \\
\hline & & \multirow{2}{*}{$\frac{n}{780}$} & \multirow{2}{*}{$\begin{array}{c}\% \\
85.71\end{array}$} & \multirow{2}{*}{$\frac{n}{47}$} & \multirow{2}{*}{$\begin{array}{c}\% \\
5.16\end{array}$} & \multirow{2}{*}{$\begin{array}{c}n \\
12\end{array}$} & \multirow{2}{*}{$\begin{array}{c}\% \\
1.31\end{array}$} & \multirow{2}{*}{$\begin{array}{c}\mathrm{n} \\
18\end{array}$} & \multirow{2}{*}{$\frac{\%}{1.98}$} & \multirow{2}{*}{$\begin{array}{c}\mathrm{n} \\
53\end{array}$} & \multirow{2}{*}{$\begin{array}{c}\% \\
5.82\end{array}$} \\
\hline 1. & $\begin{array}{l}\text { Drinking tap } \\
\text { water }\end{array}$ & & & & & & & & & & \\
\hline 2. & Black tea & 271 & 29.78 & 373 & 40.99 & 157 & 17.25 & 19 & 2.09 & 90 & 9.89 \\
\hline 3. & Cola drink & 26 & 2.86 & 208 & 22.86 & 431 & 47.36 & 154 & 16.92 & 91 & 10.00 \\
\hline 4. & Fruit juice & 298 & 32.75 & 431 & 47.36 & 80 & 8.79 & 10 & 1.10 & 91 & 10.00 \\
\hline 5. & Energy drink & 12 & 1.32 & 85 & 9.34 & 250 & 27.47 & 475 & 52.20 & 88 & 9.67 \\
\hline 6. & $\begin{array}{l}\text { Beer and other } \\
\text { alcoholic bever- } \\
\text { ages }\end{array}$ & 28 & 3.08 & 81 & 8.90 & 218 & 23.96 & 493 & 54.17 & 90 & 9.89 \\
\hline 7. & $\begin{array}{l}\text { Coffee with } \\
\text { caffeine }\end{array}$ & 24 & 2.64 & 185 & 20.33 & 372 & 40.88 & 240 & 26.37 & 89 & 9.78 \\
\hline 8. & $\begin{array}{l}\text { Mineral water, } \\
\text { medium miner- } \\
\text { alised }\end{array}$ & 374 & 41.10 & 349 & 38.35 & 57 & 6.26 & 17 & 1.87 & 113 & 12.42 \\
\hline 9. & $\begin{array}{l}\text { Bottled non- } \\
\text { carbonated } \\
\text { spring water }\end{array}$ & 555 & 60.99 & 179 & 19.67 & 31 & 3.41 & 19 & 2.09 & 126 & 13.85 \\
\hline 10. & $\begin{array}{l}\text { Sweetened } \\
\text { lemonade }\end{array}$ & 44 & 4.84 & 276 & 30.33 & 394 & 43.30 & 104 & 11.43 & 92 & 10.11 \\
\hline 11. & $\begin{array}{l}\text { Slightly miner- } \\
\text { alised water }\end{array}$ & 384 & 42.20 & 315 & 34.62 & 74 & 8.13 & 20 & 2.20 & 117 & 12.86 \\
\hline 12. & $\begin{array}{l}\text { Carbonated } \\
\text { drink }\end{array}$ & 38 & 4.18 & 298 & 32.75 & 357 & 39.23 & 106 & 11.65 & 111 & 12.20 \\
\hline 13. & Green tea & 312 & 34.29 & 336 & 36.92 & 148 & 16.26 & 24 & 2.64 & 90 & 9.89 \\
\hline 14. & $\begin{array}{l}\text { Lemonade } \\
\text { sweetened } \\
\text { with artificial } \\
\text { sweetener }\end{array}$ & 28 & 3.08 & 114 & 12.53 & 322 & 35.38 & 350 & 38.46 & 96 & 10.55 \\
\hline
\end{tabular}

Note: The grey boxes indicate the correct categorisation of the drinks in terms of their recommended amount of daily consumption. The results in bold indicate the correct results that did not achieve the $50 \%$ threshold.

The correct categorisation of the drinks in terms of their recommended amount by girls and boys is shown in Figure 4. A statistically significant difference in the frequency of the correct responses between girls and boys was observed in seven sub-items of the test task, always in favour of girls. Specifically, this applied to the following drinks: drinking tap water, black tea, cola drink, energy drink, beer and other alcoholic beverages, coffee with caffeine and sweetened lemonade. 


\section{Figure 4}

Analysis of the correct categorisation of the drinks in terms of their recommended daily consumption by gender

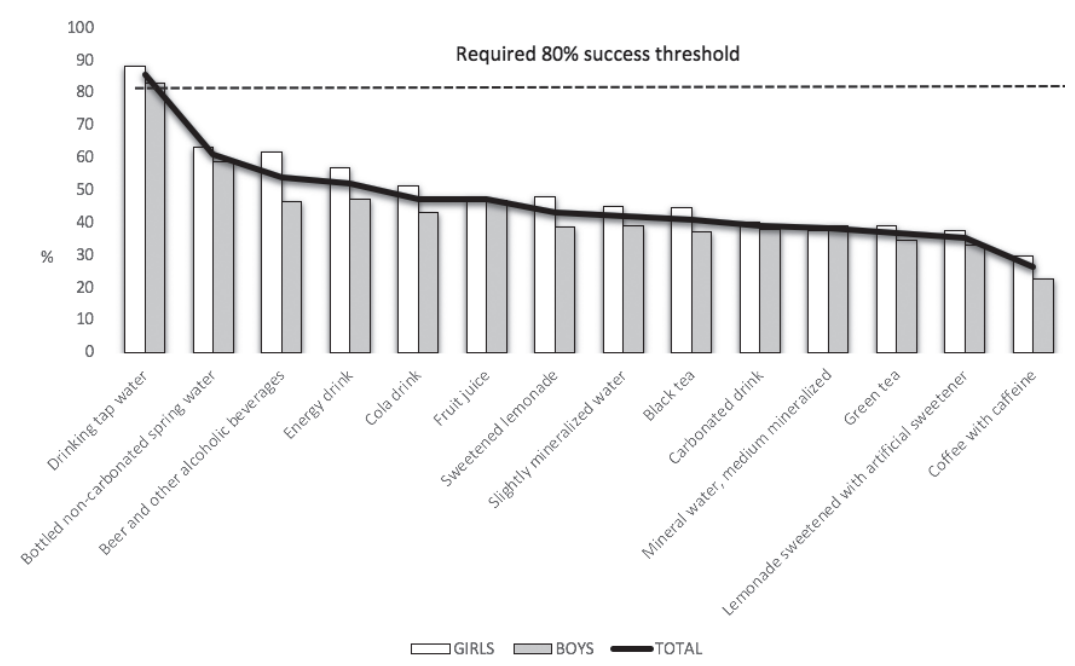

The evaluation of pupils' educational outcomes at the end of compulsory education relating to the expected outcome 7 in health education suggests a problematic level of pupils' knowledge in the area of fluid intake. It is thus desirable to look for educational ways to improve this situation. One option is to use appropriate teaching methods and didactic resources to promote more effective education and better reinforcement of the knowledge learned. The text below presents possible didactic resources and the application of the research results in practice.

\section{Application of the research results in the development of methodological resources and suggestions for suitable didactic resources for nutrition and health}

The research study Research of the level of adopted curriculum by elementary school students in Health education not only evaluated the educational outcomes of pupils from grade nine of elementary schools but at the same time the degree of difficulty of the illustrative tasks included in the Standards for elementary education - Health education (2015). In the development of the standards, the authors designed them so as to be achieved by $80 \%$ of pupils. At the same time, the individual tasks were designed so that the majority of pupils could 
achieve at least $80 \%$. The testing results of the tasks were subsequently used in the development of the document Methodological guidelines and tasks for the Standards for elementary education - Health education (2016), which is an accompanying curricular document to the educational standards. Compared with the educational standards, this document is more extensive in terms of content and methodology and includes illustrative tasks for each expected outcome pursuant to FEP EE at three levels of difficulty (minimal, optimal and excellent). The present research allowed the decision as to whether the original illustrative task from the Standards for elementary education - Health education (2015): (1) remains unchanged at a minimal level of difficulty, (2) with the same text has been transformed into an optimal or excellent level of difficulty, (3) has been modified for a minimal level of difficulty (simplified in terms of content or didactic aspects) while the original version has been transformed into an optimal level of difficulty, (4) has been simplified in terms of content and didactic aspects for a minimal level of difficulty and transformed for an optimal level of difficulty while the identical (or modified) version has been transformed into an excellent level. At the same time, the methodological guidelines include new illustrative tasks, which represent an alternative to the correct solution and provide an additional didactic procedure and possible alternatives for using the task.

The testing (see Figure 5 for an example of a pupil solution) and the results of the illustrative task relating to the expected outcome HE-9-1-07 which, concerning the required general level of achievement as well as individual task achievement of $80 \%$, was ranked last of the sixteen test tasks (Hřivnová, 2018d) and indicated a need for a didactic transformation (simplification) and content correction for the minimum and optimal level of difficulty (for the excellent level of difficulty no content reduction was performed). 


\section{Figure 5}

Pupil solution of test task 7

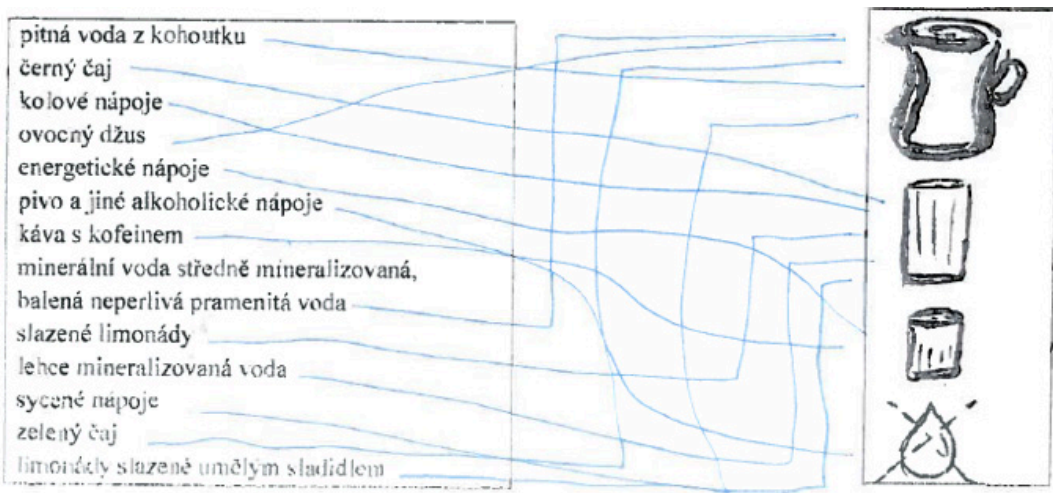

Note. Given that the test was in the Czech language and the figure reflects the identical pupil solution, the figure is in Czech; the order of the drinks in the list corresponds to the assignment of the test task described in English above. Illustrative tasks of HE-9-1-07 included in the Standards for elementary education - Health education (2015, p. 9).

From a didactic perspective, the testing of the tasks showed that matching the answers using a line was very problematic and could lead to an incorrect task assessment. Therefore, the symbols were identified by the letters A-D, which pupils could write next to the drinks. The content reduction in the number of drinks within the three levels of difficulty of the illustrative task was based on empirical data, meaning the numbers of the correct categorisations of the drinks by pupils from grade nine of elementary schools. At the same time, however, in designing the innovated version of the task, the logical framework of the task was maintained to allow the drinks' inclusion into all four categories of the daily consumption for the minimal and optimal level of difficulty.

An example is an adaptation of the illustrative task for HE-9-1-07 for the minimal level of difficulty (Figure 6) in the same version as in the Methodological guidelines and tasks for the standards for elementary education - Health education (Tupý et al., 2016, pp. 47-48). The full version of the task for the optimal and excellent levels is in the abovementioned document on pages 48-51. 


\section{Figure 6}

Illustrative task relating to HE-9-1-07 modified for the minimal level of difficulty

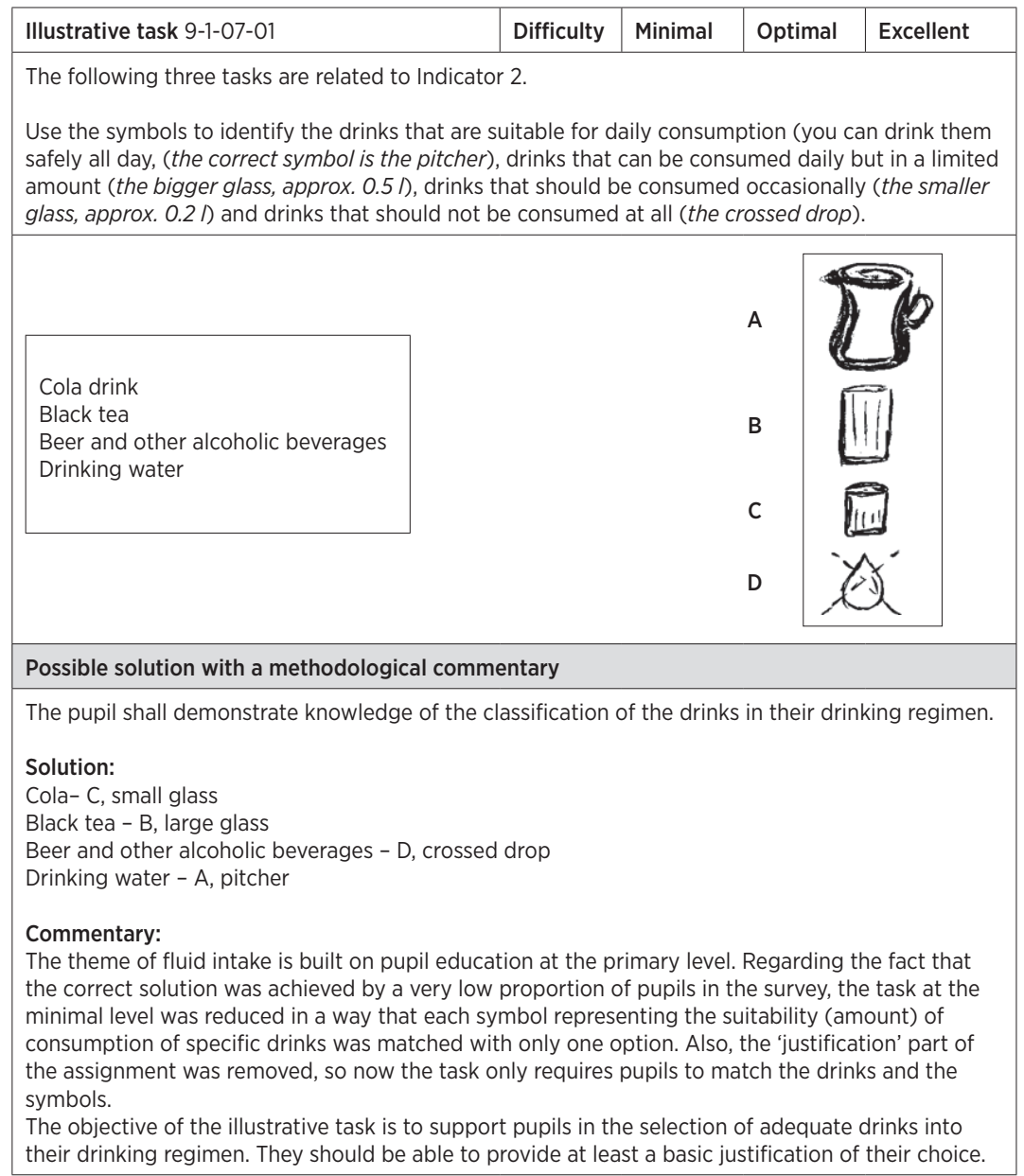

Note. Adapted from Tupý et al., 2016, pp. 47-48.

It can thus be concluded that the 'missing' methodological platform for health education teachers should be supported by the development and existence of the document Methodological guidelines and tasks for the Standards for elementary education - Health education (2016) which also contains the results of the project Research of the level of adopted curriculum of elementary school pupils in Health education.

However, many other methodological and didactic resources on health education, including the area of nutrition, but not all, as suggested by Slaná 
Reissmanová and Smejkalová (2018), are built on appropriate professional theoretical content or optimal methodological and didactic elaboration. In the Czech Republic, textbooks certified by the Ministry of Education, Youth and Sports are provided directly for the area of nutrition under the field of health education. Marádová and Hrnčírová (2020) prepared a series of two textbooks separately for grades six and seven and for grades eight and nine (currently being prepared for publication) of elementary schools and corresponding grades of multi-year grammar schools entitled Nutrition in Health Education. The textbooks are also provided with workbooks. The textbooks and workbooks are available in an electronic form on the website of the Ministry of Agriculture, which was responsible for their publication. In an interactive way, they teach and develop nutrition literacy and encourage the application of appropriate eating habits. An appropriate didactic resource to promote health education that includes nutrition is the We're Not Afraid of Cancer or Prevention as a Doorway to Health. Oncological Prevention Methodology for Lower Secondary Schools, which the authors published both in Czech (Smejkalová \& Slaná Reissmannová, 2018) and English (Slaná Reissmannová \& Smejkalová, 2020). The same authors produced didactic suggestions for a series of 10 teaching units of health education in the publication Decide! Or Lifestyle for Health (Smejkalová \& Slaná Reissmannová, 2019). All three methodological publications are available on the Decide for Health website. Finally, methodological recommendations in nutrition based on the Slovenian education system are available in the textbook Gospodinjstvo 6 [Učbenik za gospodinjstvo $v$ šestem razredu osnovne šole] (Kostanjevec, 2019).

\section{Ethical aspects and limitations of the research}

All of the stages of Research I and II complied with the Ethical Code of Czech for science and research. The core attributes of the ethics of scientific work were taken into consideration.

Naturally, as in other research studies, the present research has limitations. The most important limitation relates to the common risks associated with the application of questionnaires. Also, a certain limitation is the polyfactorial effect on the development of the implemented and achieved curriculum of health education in the context of the fact that it is not realistic within a single research study to capture and contextualise all possible variables. 


\section{Conclusion and practical recommendations}

The results of the two curricular research studies carried out by the Faculty of Education, Palacký University Olomouc suggest that nutrition is a dominant theme within health education in the Czech Republic. At the same time, the results point to a poor level of knowledge among pupils at the end of compulsory education related to quantitative and qualitative aspects of fluid intake compared to the state level of the implemented curriculum. The low level of nutrition literacy should become a stimulus for searching for appropriate didactic procedures to develop the interactive and critical level of pupils' health literacy. It would also be desirable to ensure that teachers teach health education with professional and didactic competence.

At the same time, further curricular research studies should be performed focusing on health education to improve the quality of education and to achieve the required educational outcomes. Health education also deserves a curricular research study at an international level to make a comparison between countries in terms of the intended, implemented, and adopted curricula. Currently, there is a significant shortage of these types of research studies.

\section{References}

Doležel, Z. (2007). Pitný režim u dětí [Fluid intake in children]. Pediatrie pro praxi,, 3, 136-138. Dostálová, J., \& Tláskal, P. (2021). Výživová doporučení pro obyvatelstvo [Dietary guidelines for the population]. Výživa a potraviny, $76(1), 25$.

Erjavšek, M., Lovšin Kozina, F., \& Kostanjevec, S. (2021). In-service home economics teachers' attitudes to the integration of sustainable topics in the home economics subject. Center for Educational Policy Studies Journal, 11(1), 27-47.

Fialová, L., Flemr, L., Marádová, E., \& Mužík, V. (2014). Vzdělávací oblast Člověk a zdraví v současné škole [Educational area Man and health in the current school]. Karolinum.

Fraňková, S., Pařízková, J., \& Malichová, E. (2013). Jídlo v životě dítěte a adolescenta: teorie, výzkum, praxe [Food in the life of the child and adolescent: Theory, research, practice]. Karolinum.

Gavora, P. (2010). Úvod do pedagogického výzkumu [Introduction to pedagogical research]. Paido. Health 2020. A European policy framework and strategy for the 21st century. (2013). World Health Organization, Regional Office for Europe,

Health 21: the health for all policy framework for the WHO European region (1999). European health for all series; No. 6. World health organization, regional office for Europe.

Hendl, J. (2006). Přehled statistických metod zpracování dat: analýza a metaanalýza dat [Overview of statistical data processing methods: data analysis and meta-analysis]. Portál.

Holčík, J., Káňová, P., \& Prudil, L. (2015). Systém péče o zdraví a zdravotnictví: východiska, základní 
pojmy a perspektivy [Healthcare and public health: background, basic concepts and perspectives]. Národní centrum ošetřovatelství a nelékařských zdravotnických oborů.

Hrnčírová, D. (2018). Výživa ve výchově ke zdraví: pracovní sešit pro žáky 6. a 7. tříd ZŠ [Nutrition in health education: workbooks for $6^{\text {th }}$ and $7^{\text {th }}$ graders]. Ministerstvo zemědělství, Odbor bezpečnosti potravin. https://www.bezpecnostpotravin.cz/UserFiles/publikace/6-7_nahled_1.pdf Hrnčírová, D., \& Marádová, E. (2020). Výživa ve výchově ke zdraví. Učebnice pro 6. a 7. ročník základních škol a odpovídající ročníky víceletých gymnázií [Nutrition in health education. Textbook for the $6^{\text {th }}$ and $7^{\text {th }}$ grades of elementary schools and corresponding grades of multi-year grammar schools]. Ministerstvo zemědělství, Odbor bezpečnosti potravin. https://www.bezpecnostpotravin. cz/UserFiles/publikace/U\%C4\%8Debnice\%2oWeb\%2ofin_dol.pdf Hřivnová, M. (2014a). The conception of health education at primary schools in the Czech Republic. In SGEM Conference on psychology \& psychiatry, sociology \& healthcare education (pp. 899-912). International Multidisciplinary Scientific Conferences on Social Sciences and Arts. Albena. 10.5593/ sgemsocial2014/B12/S2.115

Hřivnová, M. (2014b). Základní aspekty výživy [Basic aspects of nutrition]. Univerzita Palackého v Olomouci.

Hřivnová, M. (2016). Health literacy in pupils in the context of research of resulting curriculum of health education. The Anthropologist - International Journal of Contemporary and Applied Studies of Man, 24(1), 277-283.

Hřivnová, M. (2017). Analýza úrovně dosaženého kurikula žáky v kontextu standardu pro základní vzdělávání ve vzdělávacím oboru Výchova ke zdraví [Analysis of the level of the achieved curriculum in the context of the Standard for elementary education in the educational field of health education]. Acta Humanica, 2(1), 74-93.

Hřivnová, M. (2018a). Standardy pro základní vzdělávání - Výchova ke zdraví a jejich evaluace $v$ prostředí pedagogické reality [Standards for elementary education - Health education and its evaluation in the context of pedagogical reality]. E-Pedagogium, 2018(1), 87-101.

Hřivnová, M. (2018b). Subjective evaluation of health education by Czech students. In The European Proceedings of Social \& Behavioural Sciences EpSBS (pp. 575-584). Future Academy. Athens. https:// doi.org/10.15405/epsbs.2019.01.55

Hřivnová, M. (2018c). Selected aspects of subjective evaluation of health education by elementary school students in the Czech Republic. In 5th International Multidisciplinary Scientific Conference on Social Sciences and Arts SGEM 2018 (pp. 631-638). International Multidisciplinary Scientific Conferences on Social Sciences and Arts. Albena. https://doi.org/10.5593/sgemsocial2018/3.4/S13.080 Hřivnová, M. (2018d). Analýza a evaluace kurikula vzdělávacího oboru Výchova ke zdraví [Analysis and evaluation of the health education curriculum]. Habilitační práce. Univerzita Palackého v Olomouci.

Chráska, M. (2007). Metody pedagogického výzkumu [Methods of pedagogical research]. Grada. Kalman, M., Sigmund, E., Sigmundová, D., Hamř́ik, Z., Beneš, L., Benešová, D., \& Csémy, L. (2011). Národní zpráva o zdraví a životním stylu dětí a školáků na základě mezinárodního výzkumu 
uskutečněného v roce 2010 v rámci mezinárodního projektu "Health Behaviour in school-aged Children: WHO Collaborative Cross-national study (HBSC)" [National report on the health and lifestyle of children and schoolchildren on the basis of an international research study implemented in 2010 in the context of the international project "Health Behaviour in School-Aged Children: WHO Collaborative Cross-National Study (HBSC)”]. Univerzita Palackého v Olomouci. Kostanjevec, S. (2019). Gospodinjstvo 6: Učbenik za gospodinjstvo v šestem razredu osnovne šole [Home economics 6. Textbook for home economics in the sixth grade of elementary school]. Rokus Klett.

Kostanjevec, S., Lovšin Kozina, F., \& Erjavšek, M. (2018). The relationship between teachers' education and their self-perceived competence for teaching home economics. Problems of education in the 21st century, 76(2), 175-187.

Kovař́ková, M., \& Marádová, E. (2020). Didaktika výchovy ke zdraví a bezpečí v kontextu kurikulární reformy a učitelského vzdělávání [Didactics of health education and safety in the context of the curricular reform and teacher training]. Pedagogická fakulta UK Praha.

Kožišek, F. (2005). Pitný režim [Fluid intake]. http://www.szu.cz/tema/zivotni-prostredi/pitny-rezim Kučera, Z., Pelikan, J., \& Šteflová, A. (2016). Zdravotní gramotnost obyvatel ČR - výsledky komparativního reprezentativního šetření [Health literacy of the Czech population - Results of a comparative representative survey]. Časopis Lékařů českých, 155(5), 233-241.

Leahy, D., \& Simovska, V. (2017). Critical perspectives on health and wellbeing education in schools. Health Education, 117(5), 430-433. https://doi.org/10.1108/HE-06-2017-0034

Liba, J. (2016). Výchova $k$ zdraviu $v$ školskej edukácii [Health education in the system of education]. Prešovská univerzita v Prešově.

Madarasová Gecková, A., Dankulincová, Z., Sigmundová, D., \& Kalman, M. (Eds.). 2016. Mezinárodní zpráva o zdraví a životním stylu dětí a školáků na základě výzkumu studie Health Behaviour in School-Aged Children realizované v roce 2014, Česká republika, Slovenská republika, Madiarsko, Ukrajina a Polsko [International report on the health and lifestyle of children and schoolchildren on the basis of the Health Behaviour in School-Aged Children implemented in 2014, Czech Republic, Slovakia, Hungary, Ukraine and Poland]. Univerzita Palackého v Olomouci. Marádová, E. (2011). K aktuálním problémům výchovy ke zdraví v preprimárním a primárním vzdělávání [On the current problems of health education in pre-primary and primary education]. In S. Bendl \& M. Zvírotský (Eds.), Místo vzdělávání v současné společnosti: paradigmata - ideje realizace. (pp. 45-55). Tribun.

Müllerová, D. (2003). Zdravá výživa a prevence civilizačních nemocí ve schématech [Healthy nutrition and prevention of lifestyle diseases in schemes]. Triton.

Mužíková, L. (2010). Škola a zdraví pro 21. Století. Podněty pro implementaci výchovy ke zdraví do školních vzdělávacích programů [School and health for the $21^{\text {st }}$ century. Ideas for the implementation of health education in school educational programmes]. Masarykova univerzita. Nutbeam, D. (2000). Health literacy as a public health goal: a challenge for contemporary health education and communication strategies into the $21^{\text {st }}$ century. Health Promotion International, $15(3)$, 
259-267. https://doi.org/10.1093/heapro/15.3.259

Rámcový vzdělávací program pro základní vzdělávání (verze platná od 1. 9. 2013) [Framework education programme for elementary education (version valid from $1^{\text {st }}$ September 2013)]. (2013). http://www.msmt.cz/vzdelavani/zakladni-vzdelavani/upraveny-ramcovy-vzdelavaci-program-prozakladni-vzdelavani.

Rámcový vzdělávací program pro základní vzdělávání (verze platná od 1. 1. 2021) [Framework education programme for elementary education (version valid from $1^{\text {st }}$ January 2013)]. (2021). http:// www.nuv.cz/file/4983/

Rippe, J., M., \& Angelopoulos, T., J. (2017). The role of nutrition and lifestyle in the prevention and treatment of cardiovascular disease. In Nutrition in Lifestyle Medicine. (137-150). Humana Press. https://doi.org/10.1007/978-3-319-43027-0_7

SHE FACTSHEET 1. State of the art: Health promoting schools in Europe. (2013). https://www.radix. ch/files/5O8NYKY/she_factsheet_1_2013.pdf Smejkalová, Z., \& Slaná Reissmannová, J. (2018). My se raka nebojíme aneb prevencí ke zdraví. Metodický materiál onkologické prevence pro 2. stupeň základní školy [We’re not afraid of cancer or prevention as a doorway to health. Oncological prevention methodology for lower secondary schools]. Masarykova univerzita.

Smejkalová, Z., \& Slaná Reissmannová, J. (2019). Rozhodni se! aneb životním stylem ke zdraví. Metodický materiál $k$ výuce prevence onkologických a dalších chronických neinfekčních chorob pro 2. stupeň ZŠ [Decide! or lifestyle for health. Methodology for the prevention of oncological and other chronic non-communicable diseases for lower secondary schools]. Masarykova univerzita. Slaná Reissmannová, J. (2021). Mezinárodní doporučení v oblasti ochrany veřejného zdraví a jejich implementace $v$ České republice s akcentem na oblast mimořádných událostí a krizových situací. Diplomová práce [International recommendations in the area of public health protection and their implementation in the Czech Republic with an emphasis on emergency and crisis situations]. Lékařská fakulta Univerzity Palackého v Olomouci. Slaná Reissmannová, J., \& Smejkalová, Z. (2020). We’re not afraid of cancer or prevention as a doorway to health. Oncological prevention methodology for lower secondary schools. Masaryk University Press.

Slaná Reissmannová, J., \& Smejkalová, Z. (2018). Analysis of a health education textbook in the context of the Framework educational programme for elementary education and possibilities of implementation of the issue of chronic non-communicable diseases in the Czech Republic. In M. Holinková, \& L. Adámková (Eds.), Life in health 2019: Research and practice. Proceedings of the International Conference held on 5-6 September 2019 (pp. 128-136). Masarykova univerzita. https:// doi.org/10.5817/CZ.MUNI.P210-9484-2019.

Rozhodni se pro zdraví [Decide for health]. (2020). https://www.rozhodniseprozdravi.cz/ Standardy pro základní vzdělávání - Výchova ke zdraví [Standards for elementary education Health education]. (2015). http://digifolio.rvp.cz/artefact/file/download.php?file=67503\&view= 9832 Svoboda, M. (2015). Př́nos vzdělávacího oboru Výchova ke zdraví z pohledu žáků základních škol 
[Benefits of the educational field health education from the perspective of elementary school pupils] In D. Šafránková, L. Podroužek, \& J. Slowík, (Eds.), Etické a sociální aspekty v oblasti vzdělávání a pedagogického výzkumu: sborník XXIII. konference České asociace pedagogického výzkumu (pp. 371-380). ZČU v Plzni.

Tláskal, P. (2021). Zdravá třináctka pro děti v kontextu s realitou současných poznatků a studií [Healthy thirteen for children in the context of the current state of knowledge and studies]. Výživa a potraviny, 76(2), 37-40.

Tupý, J., Hřivnová, M., \& Marádová, E. (Ed.) (2016). Metodické komentáře a úlohy ke standardům pro základní vzdělávání - Výchova ke zdraví [Methodological guidelines and tasks for the Standards for elementary education - Health education]. NÚV.

Van Draanen, J., Prelip, M., \& Upchurch, D. (2018). Consumption of fast food, sugar-sweetened beverages, artificially-sweetened beverages and allostatic load among young adults. Preventive Medicine Reports,10, 212-217. https://doi.org/10.1016/j.pmedr.2017.11.004.

Výběrové zjištování výsledků žáků na úrovni 5. a 9. ročníků základních škol ve školním roce $2016 / 2017$ [Sample survey of pupils in the $5^{\text {th }}$ and $9^{\text {th }}$ grades of elementary school in the school year 2016/2017]. (2017). Česká školní inspekce.

Zpráva o zdraví obyvatel České republiky [Report on the health of the citizens of the Czech Republic]. (2014). Ministerstvo zdravotnictví České republiky.

Zdraví 2030. Strategický rámec rozvoje péče o zdraví v České republice do roku 2030 [Strategic framework for the development of healthcare in the Czech Republic until 2030]. (2020). https:// zdravi2030.mzcr.cz/ 


\section{Biographical note}

Michaela Hrivnová, $\mathrm{PhD}$, is an associate professor and works at the Faculty of Education, Palacký University Olomouc (PdF UP) at the Department of Anthropology and Health Education. She was Head of Department in 20132015. At present, she is Head of the Centre for Research of Healthy Lifestyle. In her teaching and scientific-research activity she focuses on the curriculum of health education, didactics of health education as well as health literacy. She is the author of the concept and professional guarantor of the study programmes Health Education and Teacher Training in Health Education at PdF UP. She was involved in the development of Standards for Elementary Education - Health Education in cooperation with the Ministry of Education, Youth and Sports. Currently, she participates in the review of the curriculum of the area Humans, Their Personality, Health and Safety in cooperation with the National Pedagogical Institute of the Czech Republic. She is an active member of professional societies, their boards as well as scientific committees. She is a reviewer of textbooks pending the award of the certification clause by the Ministry of Education, professional journals as well as scientific and methodological publications. She cooperates with state and non-profit organizations participating in health promotion activities, development of health literacy and prevention of risk behaviour. She has a wide portfolio of national as well as international lecture and conference activities, publications, projects and grants. 